\title{
MISCELIANEA GEOGRAPHICA
}

Vol. 14/2010

pp. 13-19

\author{
Alina Gerlée \\ University of Warsaw \\ Faculty of Geography and Regional Studies \\ Department of Geoecology \\ email: a.gerlee@uw.edu.pl
}

\section{LANDSCAPE REPRESENTATIVENESS WITHIN THE NETWORK OF ECOLOGICAL CORRIDORS LINKING NATURA 2000 AREAS IN POLAND}

\begin{abstract}
This paper analyses landscape representativeness within the ecological corridor network linking Natura 2000 areas in Poland. The criteria used to designate the network did not include landscape representativeness. Nevertheless, the selection of areas covered by the network was found to be adequate to preserve landscape diversity in Poland. The selected areas include the most valuable parts of various landscape types.
\end{abstract}

Key words: ecological network, landscape representativeness, landscape protection, ecological corridors.

\section{INTRODUCTION}

The Natura 2000 European Ecological Network has been developing within the European Union since 1992. It assumes a methodologically and organisationally uniform procedure of protected areas designation within all member states ${ }^{1}$. Natura 2000 comprises two types of areas, identified according to scientific (natural) criteria: Special Protection Areas (SPAs) for birds, and Special Areas of Conservation (SACs) for habitats.

An ecological corridor constitutes an especially important element of the natural environment and is central to preserving biodiversity on various levels. There have been earlier attempts to plan ecological networks (including corridors) in Poland. The most advanced, although never implemented project was ECONET-Polska (Liro, 1995, 1998).

\footnotetext{
${ }^{1}$ The legal basis of the Natura 2000 network is the Council Directive 79/409/EEC of 2 April 1979 on the conservation of wild birds (i.e. Birds Directive) and Council Directive 92/43/EEC of 21 May 1992 on the conservation of natural habitats and of wild fauna and flora (i.e. Habitats Directive).
} 
In 2005, the Ministry of the Environment commissioned designing a plan of ecological corridors linking Natura 2000 areas in Poland (Jędrzejewski et al., 2005). Information concerning this project is available on the special Ministry of Environment website dedicated to Natura 2000 (Natura... 20042005). The obligation to protect ecological corridors stems from the regulations of the Habitat Directive, which outlines the necessity to preserve homogeneity within the Natura 2000 network. However, the concept of ecological corridors is not a separate, legally sanctioned means of nature protection in Poland.

Jędrzejewski et al. (2005) point out that the ECONET-Polska ecological network plan (Liro, 1995, 1998) is too much limited to the watercourse system, thereby neglecting land habitats. The criteria adopted in the ECONET-Polska project create a bias towards watercourses, waterbodies and adjacent areas. This results in lack of habitat continuity necessary for migration of land species, and in particular rare forest species.

According to its authors, the proposed "Plan of ecological corridors linking the Ecological Network Natura 2000 in Poland" (Jędrzejewski et al., 2005) covers effective animal and plant migratory routes in Poland, which link their populations east of Poland with the populations west and south of Poland.

The criteria for designation of corridors in this project included high forest cover (main criterion); absence of anthropogenic barriers; presence of watercourses, waterbodies and wetlands; presence of protected areas; appropriate type of land use on areas between forest patches (preference was given to meadows and wasteland which can potentially be afforested, and areas providing shelter for fauna and allowing migration, such as groups of trees and shrubs on fields); indicator species range and their historic (documented or reconstructed) migration routes. The network incorporates most legally protected areas and, where possible, river valleys, as long as they are without dense housing. The selection process took into account also analyses of historic and current migration routes of indicator species (predominantly wolves and lynx) as well as available results of genetic studies (primarily wolf populations in Central and Eastern Europe). These studies indicate that recolonisation of Western Poland by wolves is fed by the lowlands in the north of Poland, rather than the south. Designation of ecological corridors was performed taking into account all previous projects (Liro, 1995, 1998; Kiczyńska, Weigle, 2003; Jędrzejewski et al., 2004).

Four landscape types are identified in Poland: lowlands, highlands and low-elevation mountains, mid- to high-elevation mountains, and valleys and depressions. They are subdivided into landscape genera, species types and varieties. The criteria used to distinguish genera and species within types depend on the dominant landscape modelling factor in a given landscape type (Richling, Ostaszewska, 2006).

The goal of the present study was to assess whether the project by Jędrzejewski et al. (2005) ensures an adequate degree of protection of vari- 
ous landscape types in Poland. While designating corridors and their boundaries the authors did not consider the criteria of landscape and habitat representativeness.

\section{MATERIALS AND METHODOLOGY}

The source material was the "Plan of ecological corridors linking the European Natura 2000 network in Poland" (Jędrzejewski et al., 2005). In addition, a map of natural landscape types was used (Richling, Dabrowski, 1995). The area of each landscape category was analysed, for the whole Poland and within the examined network of ecological corridors. The representativeness of the landscape types included in the network was assessed relative to the country as a whole. Our indicator of representativeness was the proportion of a given landscape type area within the designated corridor network, relative to its percentage area in Poland.

\section{RESULTS AND DISCUSSION}

The ecological corridor network (Fig. 1) covers $36 \%$ of Poland's area. The relative proportions of different landscape types within the ecological corridors are comparable to their relative proportions in the total area of Poland

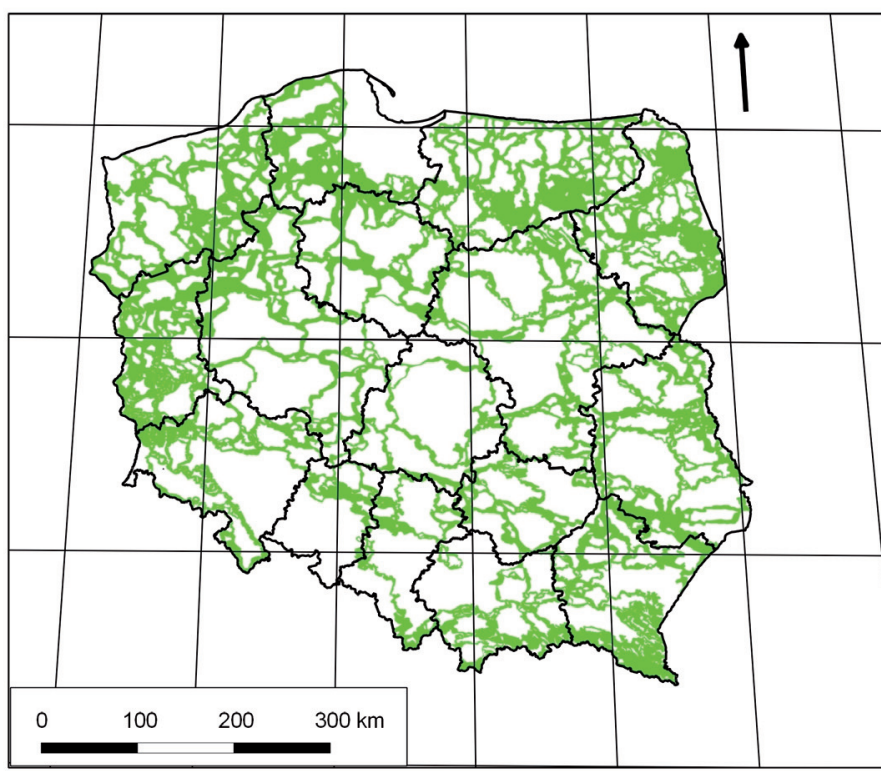

\section{Legend}

Ecological corridors

Voivodship boundaries

Fig. 1. Plan of ecological corridors linking Natura 2000 European Network areas in Poland (Jędrzejewski et al., 2005) 
(Fig. 2). The largest, although still relatively small difference was observed in the case of valleys and depressions - their proportion within the network is 5\% higher compared to Poland's overall area.

The corridor network has incorporated $65 \%$ mid- to high-elevation mountains, $45 \%$ valleys and depressions, $35 \%$ lowlands and $29 \%$ highlands and low-elevation mountains (Fig. 3).

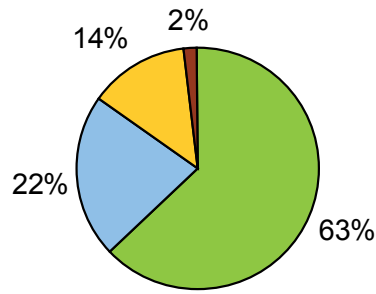

1.

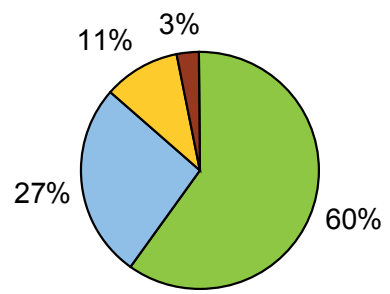

2.

\section{$\square$ Lowlands}

$\square$ Valleys and depressions

$\square$ Highlands and low mountains

$\square$ Mid- and high mountains

Fig. 2. Proportions of landscape types within the area of Poland (1) and within the area of ecological corridors (2)

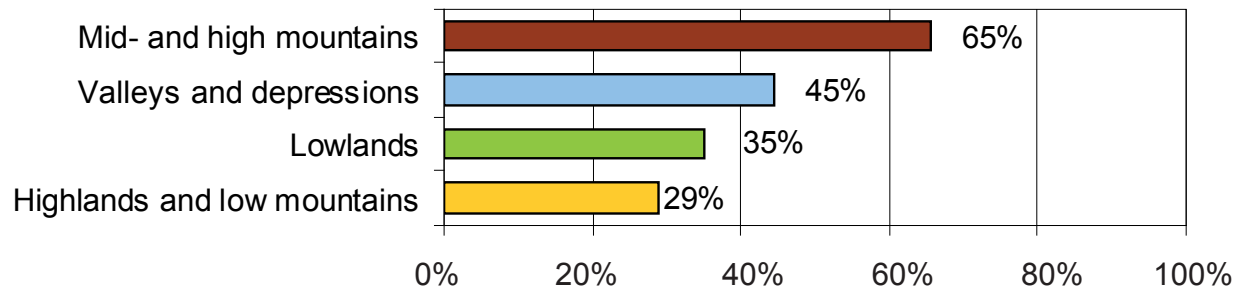

Fig. 3. Proportion of Poland's landscape types incorporated into the analysed network of ecological corridors

Within the valley and depression landscape type the most frequent landscapes were those associated with river valleys - fluvial terraces (57\%) and floodplains $(42 \%)$. The lowest proportion in this category was represented by delta landscapes. This is likely due to high soil fertility and the resulting intensive land use in these regions. Consequently, there is a low proportion of natural and semi-natural terrains that can function as migration corridors in this region.

Mid- to high-elevation mountain landscapes constituted a relatively small percentage of Poland's area (less than $2 \%$ ), however, they were included in the network for their high natural value. As much as 78\% of Poland's highelevation and $65 \%$ of mid-elevation mountains are covered by the network. The proportions are comparable in the case of lowlands of aeolian origin (sand dunes). They represent less than 1\% of Poland's area, but as much as $70 \%$ of their area has been covered by the ecological network. As with mountain landscapes, these are areas of high natural value, often protected 
as Natura 2000 areas or under other forms of legal protection. Moreover, due to poor soils these landscapes are not exploited for agriculture.

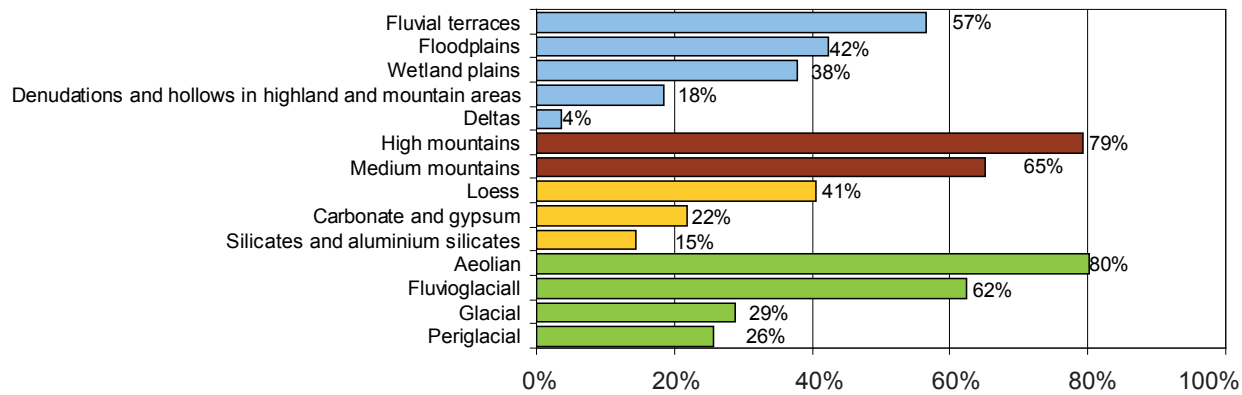

Fig. 4. Proportion of landscape types within the analysed network of ecological corridors in Poland. Colour codes: Blue - Valleys and depressions; Brown - mid- to high-elevation mountains; Yellow - highlands and low-elevation mountains; Green - lowlands

Table 1. Occurrence of different landscape types in the analysed ecological network and in Poland

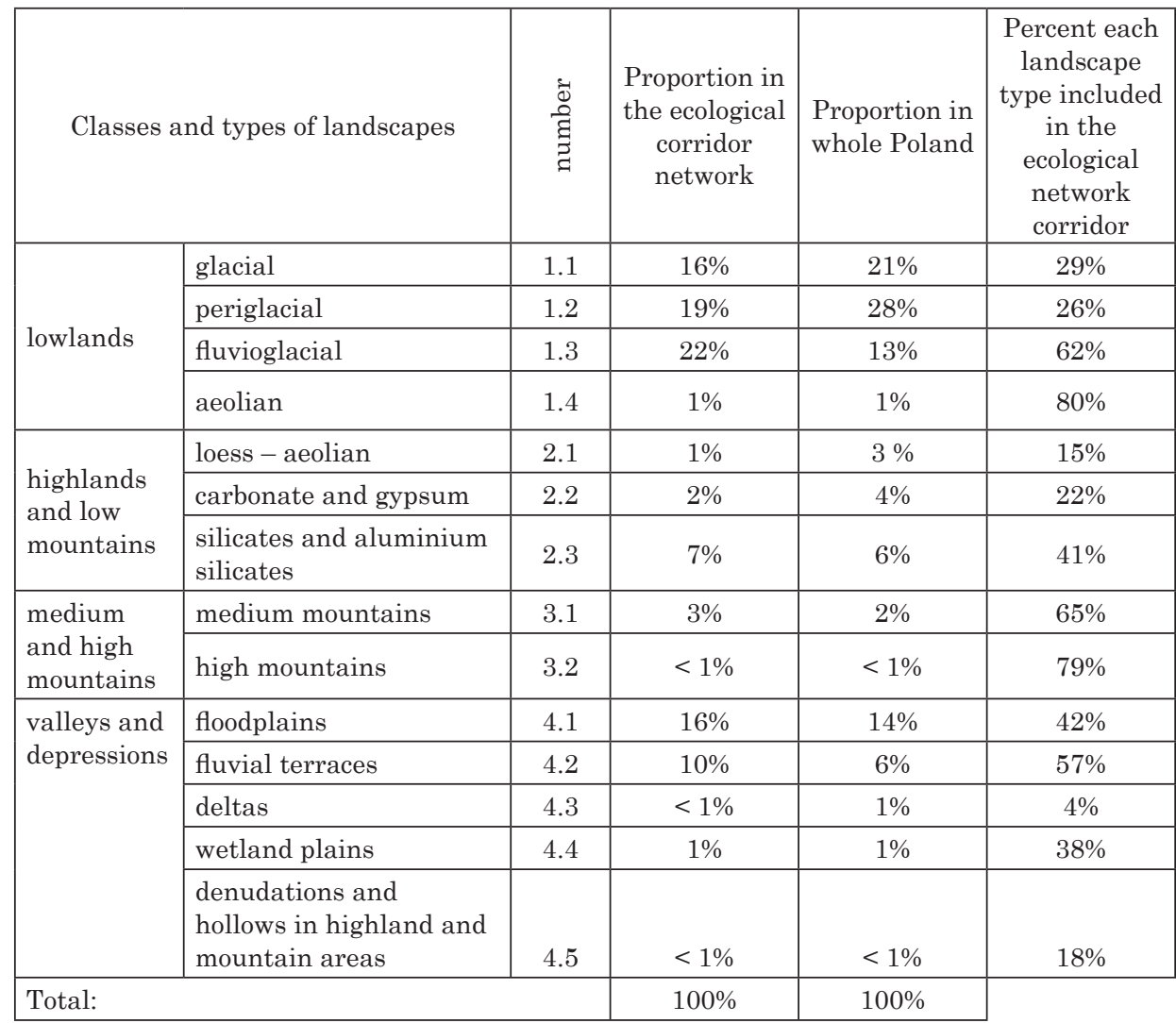


Within highlands and low-elevation mountains included in the network, the largest area was made up by loess landscapes (41\%). This may be linked to the presence of erosion gullies, which host patches of semi-natural vegetation within fertile agricultural land. Fig. 4 shows percentage representation of landscape types and Table 1 summarises all results.

\section{CONCLUSIONS}

The planned network of ecological corridors linking Natura 2000 areas (Jędrzejewski et al., 2005) appears to adequately protect various landscape types in Poland.

Analyses of various landscape classes and types within the selected ecological network support the hypothesis that the criteria adopted by the authors of the project to designate ecological corridors are also adequate for the preservation of Poland's landscape diversity.

Notably, rare and valuable landscapes that represent a relatively small percentage of Poland's overall area are well represented within the network, while landscapes that are less common and of lower ecological value cover a relatively smaller area proportion in the network.

The criteria used to designate the ecological corridor network have led to the inclusion of the most naturally valuable areas, representing various landscape types. They are characterised by the highest naturalness mainly forest ecosystems and areas with semi-natural vegetation (meadows, wasteland), and extensively used farmland. Protection of migration routes will simultaneously allow to protect geodiversity, by preserving the most valuable areas within each type of landscape.

\section{REFERENCES}

Council Directive 79/409/EEC of 2 April 1979 on the conservation of wild birds.

Council Directive 92/43/EEC of 21 May 1992 on the conservation of natural habitats and of wild fauna and flora.

Jędrzejewski W., Nowak S., Kurek R., Mysłajek R. W., Stachura K., 2004, Zwierzęta a drogi. Metody ograniczania negatywnego wptywu dróg na populacje dzikich zwierzat. [Animals and roads: methods of reducing the negative impact of roads on wild animal populations], Zakład Badania Ssaków PAN, Białowieża.

Jędrzejewski W. et al., 2005, Projekt korytarzy ekologicznych taczacych europejskq sieć Natura $2000 \mathrm{w}$ Polsce. [Plan of ecological corridors linking the Natura 2000 network in Poland], Opracowanie wykonane dla Ministerstwa Środowiska w ramach realizacji programu Phare PL0105.02. Zakład Badania Ssaków PAN, Białowieża.

Kiczyńska A., Weigle A., 2003, Jak zapewnić spójność sieci Natura 2000, czyli o korytarzach ekologicznych. [Ensuring the cohesion of the Natura 2000 network: ecological corridors] [in] Makomaska-Juchiewicz M., Tworek S. (ed.), Ekologiczna sieć NATURA 2000: Problem czy szansa. [The Natura 2000 ecological network: problem or opportunity], Instytut Ochrony Przyrody PAN, Kraków. 
Liro A. (ed.), 1995, Koncepcja krajowej sieci ECONET-Polska. [A scheme of the the ECONET Polska national network], Fundacja IUCN Poland, Warszawa.

Liro A. (ed.), 1998, Strategia wdrażania krajowej sieci ekologicznej ECONET-Polska. [The implementation strategy of the ECONET-Polska national ecological network], Fundacja IUCN Poland, Warszawa.

Natura 2000 European Ecological Network - Poland, website of the Ministry of the Environment, 2004-2005, http://natura2000.mos.gov.pl/.

Richling A., Dąbrowski A., 1995, Typy krajobrazów naturalnych. [Types of natural landscapes], Atlas Rzeczypospolitej Polskiej (Atlas of the Polish Republic). Główny Geodeta Kraju. PPWK. Warszawa.

Richling A., Ostaszewska K. (eds), 2006, Geografia fizyczna Polski [The physical geography of Poland], Wydawnictwo Naukowe PWN, Warszawa. 